\title{
A zsidóság belső forrásai a MNL, Országos Levéltárának forrásanyagában, 1760-1848
}

\author{
The Internal Sources of the Jews in the Source Material of MNL \\ (Hungarian National Archives) 1760-1848
}

\section{Mislovics E.}

\begin{abstract}
Szegedi Tudományegyetem, Történeti Segédtudományok Tanszék mislovicse@yahoo.com
\end{abstract}
Absztrakt

A tanulmány az MNL, Országos Levéltárának feudáliskori forrásgyüjteményeiben a zsidóság eredeti, még nem publikált dokumentumainak az összegyüjtésének tapasztalatait, valamint komplex analizisét helyezi a középpontba a 18. század második felétöl 1848-ig.

Az eredeti belsö források felkutatása a kormányszervi iratok áttekintésével vette kezdetét a vizsgált korszakban. A Kancelláriai Levéltár, Acta Generalia (A 39) illetve a Helytartótanácsi Levéltár, Departamentum Judaeorum (C 55) állagai olyan gyüjtemények, amelyek a közigazgatás felsöfokú és másodfokú szerveinek a középfokú közigazgatási hatóságokkal való kapcsolattartásának dokumentumait örzik. Amig a Kancelláriai Levéltár forrásanyaga az általános ügyek, addig a Helytartótanácsi Levéltár, Departamentum Judaeorum állaga a zsidóságra vonatkozó ügyek iratanyagának örzője. Az elözetes feltételezéseket beigazolva a gyüjtemények böséges belsö forrásanyagot tartalmaznak. A dokumentumok komplex analizisre engednek teret az iratanyag keletkezési idejére, számára, geográfiai megoszlására, valamint tartalmukra vonatkozóan. A források a zsidóság történelmének alaposabb megismerését teszik lehetővé, letelepedésüket, gazdasági, kulturális, vallási életüket és a keresztény társadalommal való kapcsolatrendszerüket illetöen. Úgy, hogy azok a korabeli zsidó társadalom tagjainak megfogalmazásában kerülnek a kutatók elé a dokumentumok lapjain. A kutatási tapasztalatok alapján levonható következtetés, hogy a források döntö többsége Pest megyéböl származik, azon belül is Pest városhoz köthetö. Az újkori Magyar Királyságban élö zsidóság történelmének megismeréséhez célszerü ezeket a belső forrásokat felkutatni más megyék dokumentumanyagában is. Ezért jövöbeli célként fogalmazódhat meg a megyei levéltárak anyagainak átnézése. Ez lehetöséget biztosit annak összevetésére, hogyan egészíti ki az országos levéltár állagaiban megtalálható iratanyagot a megyei levéltári anyagok gyüjteménye. Ugyancsak elörelépést jelenthetne olyan adatbázis kialakitása, amely jelzet, név, hely, tárgymutató, rövid regeszta feltüntetésével összekapcsolná az országos és megyei levéltárakban fellelhetö forrásokat. A rendelkezésre álló belsö forrásanyag a 17-19. századi zsidóság eddig ismert történelmét árnyalhatja és új ismeretekkel gazdagithatja.

Kulcsszavak: Belsö forrás. zsidóság, társadalomtörténet, gazdaságtörténet, kultúrtörténet

\section{Abstract}

The study is focused on the collection and complex analysis of the original, yet unpublished Jewish documents in the feudal source collections of MNL, Hungarian National Archives from the second half of the 18th century until 1848 .

The search for original internal sources began with a review of government records during the period under review. The collections in the Chancellery Archives, Acta Generalia (A 39) and the Council of

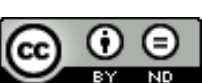


Governor-General Archives, Departamentum Judaeorum (C 55) maintain the documents of the first and second instance bodies of the public administration in their relations with the intermediate administrative authorities. The source material in the Chancellery Archives presents mostly records of general affairs, whereas the Departamentum Judaeorum collection of the Council of Governor-General contains Jewish-related issues. In support of the presumptions, the collections are rich in Jewish-related internal, historical sources. The documents allow for a complex analysis of the time, number, geographical distribution, and content of the document collections. The sources contribute to a better understanding of the history of the Jews, their settlement, their economic, cultural, religious life, and their system of relations with Christian society. The document pages present their content to researchers in the wording of the members of contemporaneous Jewish society. Based on the research experience, it can be concluded that the vast majority of the sources come from Pest County, more closely from the town of Pest. Research on these inner sources in the collections of other counties is expedient to increase awareness of Jewish history in the modern Kingdom of Hungary. Therefore, the future goal of the research may be to review the materials of the county archives. It provides an opportunity to compare how the archival material in the national archives is complemented by archival collections from the counties. The development of a database could also be a step forward and could integrate the sources in national and county archives by indicating headings, names, locations, indexes, and short regestas. The available internal source material can refine and enrich the known history of 17-19th century Jews.

Keywords: Internal source, Jews, social history,, economic history, cultural history

JEL Kód: 020207 Az új- és jelenkor története

\section{Bevezetés}

A tanulmány a MNL, Országos Levéltárának feudáliskori forrásanyagában a zsidóság eredeti belső forrásainak az összegyüjtésének a tapasztalatait, valamint a dokumentumanyag komplex analízisét helyezi a középpontba a 18. század második felétől 1848-ig.

A kutatási téma kijelölését több tényező is indokolta. Az újkori magyarországi zsidóság történelmére vonatkozó forrásanyag gyüjtése kezdetben egy-egy folyóirat hasábjain megjelenő dokumentumközlés keretein belül valósult meg. ${ }^{2}$ A 20 . század kezdetén valamennyi iratanyag felkutatására vállalkozott a Magyar-Zsidó Oklevéltár, amely az 1903-1980 között kiadott köteteiben egészen a 18. század 70-es évtizedéig gyüjtötte össze a történelmi Magyarországon élő zsidóság dokumentumanyagát. ${ }^{3}$ Az utóbbi évtizedekben szisztematikus gyüjtés keretei formálódtak a Héber kútforrások, valamint a Nekem itt zsidónak kell lennem címü forrásgyüjtemények megjelentetésével. ${ }^{4}$ Azonban eddig nem helyeződött hangsúly a levéltári gyüjteményekben fellelhető belső forrásanyag módszeres (minden egyes forrás) felkutatására. Ezek a dokumentumok, amelyeket a kortársak fogalmaztak meg, elsődleges forrásként szolgálhatnak az adott korszak általános és zsidó társadalmának megismeréséhez. Összegyüjtésüket nehezíti, hogy az újkori ügyiratok magukban rejtik a belső forrásokat, a levéltárakban pedig a legtöbb esetben - egyelöre - nem létezik iratokig lemenő leírás.

Az újkori Magyar Királyságban élő zsidóság történelme nem gyökerezik a középkorban. 1526-ban a nyugati országrészek szabad királyi városai (Sopron, Pozsony, Nagyszombat) elérték a Habsburg uralkodónál a „de non tolerandis Judaeis” jogát, azaz nem kellett zsidó lakosokat megtürniük a városfalakon belül..$^{5}$ A zsidóság egykori lakóhelyeit elhagyva a visszatérés lehetőségében reménykedve a közeli földesúri birtokokra költözött. Majd az elhúzódó harcok során többségük elhagyta az országot.

\footnotetext{
${ }^{2}$ Forrásközlésre példa: A bonyhádi zsidó közösség kérelme. Közölte: Büchler Sándor a Magyar Zsidó Szemlében 1894-ben, 657-666. oldalakon.

${ }^{3}$ A sorozatnak 18 kötete jelent meg (az ötödik kötet két részből áll). Az első kötet 1903-ban, az utolsó, a 18. 1980ban jelent meg.

${ }^{4}$ Spitzer-Komoróczy, 2003.; Komoróczy, 2012.

${ }^{5} \mathrm{MZSO} \mathrm{V} / 2.325 ., 339$.
} 
A sikeres törökellenes küzdelmek időszakában egy népességében megfogyatkozott, szétzilált gazdasági helyzetủ ország került a Habsburg fennhatóság alá. Az 1660-as évektől kezdődően a zsidó betelepülők több hullámban és több irányból érkeztek a Magyar Királyság területére. ${ }^{6}$ Az újkorban továbbélő feudális jogrendszer behatárolta a zsidóság jogi helyzetét, jóllehet változások is bekövetkeztek. Amíg a középkorban, mint servi camarae az uralkodó közvetlen fennhatósága alá tartoztak, addig az újkorban a védelmezői szerepkört a helyi földesurak vették át. Ök azok akik betelepítik avagy engedélyezik a megtelepedést a birtokaikon, feljogosítva érzik magukat az adóztatásukra. Valamint a középkori uralkodói gyakorlatot átemelve, privilégiumleveleket bocsátanak ki a közösségi élet kereteinek a szabályozására. ${ }^{7}$ A zsidóság fő megtelepedési helyszínei a mezővárosok és a falvak lettek. ${ }^{8}$ A Habsburg uralkodók kezdetben a zsidóság országból való eltávolításának tervén dolgoztak, azonban a földesúri érdekek (valamint az ország gazdasági és társadalmi helyzete) miatt ennek végrehajtása kudarcba fulladt. ${ }^{9}$ Ezért az uralkodó rögzíteni kívánta, hogy a zsidóság sorsáról végső soron ő dönt. Az I. Lipót által bevezetett türelmi taxát Mária Terézia uralkodónő véglegesítette 1749-ben. ${ }^{10}$ Az országos adó kivetése nem csupán gazdasági lépésnek számított, a zsidóság társadalmi megítélését, jogi helyzetét mintegy évszázadra meghatározva türt, sőt megtürt státuszba helyezte. A magyar társadalomtól a zsidóságot elválasztotta, idegennek tekintette. 1846-ig a zsidó lakosság részéről folyamatos a törekvés a megalázó adónem eltöröltetésére. ${ }^{11}$

A levéltárakban fellelhető belső dokumentumanyag erre az időszakra vonatkozóan a korabeli viszonyokat a zsidó társadalom hangjain keresztül közvetíti, amely felbecsülhetetlen forrásértékkel bír.

\section{Kutatási helyszín}

A zsidóság belső forrásanyagának feltárásában (kezdő lépésként) a kormányszervi iratanyag áttekintése vezethetett eredményre. Mindezt indokolta az adott korszakban a zsidóságot érintő ügyek kezelésében játszott szerepük, valamint a MNL, Országos Levéltárában fennmaradt gyüjtemények kiterjedtsége.

A MNL, Országos Levéltárának anyagában a felsőfokú hatóság, a Kancelláriai Levéltár, Acta Generalia (A 39), valamint a másodfokú szerepet betöltő Helytartótanácsi Levéltár, Departamentum Judaeorum (C 55) anyagainak áttekintése valósult meg. A Kancellária kiterjedt feladatköre folyamatosan változott a korszakban. 1690-től a megyék, szabad királyi városok, kiváltságos kerületek igazgatása, gazdasági ügyeinek ellenőrzése is a felügyelete alá tartozott. A Kancelláriai Levéltár, Acta Generalia (A 39) állag az általános ügyiratai között, mintegy 3991 jelzet alatt a zsidóságra vonatkozóan kiterjedt forrásanyagot őriz az 1760-1848 közötti időszakban.

A Helytartótanács 1724-ben került megalapításra, csökkentve ezzel a Kancellária és a magyar törvényhatóságok közötti közvetlen hivatalos érintkezést. A Helytartótanács a közigazgatásban másodfokú szerepet töltött be, kapcsolatban állt a középfokú közigazgatási hatóságokkal, vármegyékkel, szabad királyi városokkal. A Kancellária leiratai a Helytartótanácshoz kerültek át, illetve ide érkeztek be a korábban említett szervek jelentései. 1783-ban a Helytartótanácson belül egy új osztály, a Departamentum Judaeorum jött létre, amelynek anyagainak levéltári állaga a zsidóságra vonatkozó korabeli forrásanyagot tartalmazza. Az anyag kiterjedtsége 32 kötet és 243 doboz.

A belső forrásanyag kizárólag átnézéssel kutatható.

\section{Kutatási eredmény - forrásanyag bemutatása}

Az Országos Levéltár két állagában mintegy 1991 belső forrás található. Az iratok jellegük szerint kérelmek, jelentések, panaszok, tanúvallomások illetve bizonyító erejü iratok (kontraktus) csoportjaiba sorolhatók.

\footnotetext{
${ }^{6}$ A teljesség igénye nélkül néhány példa a témában megjelent szakirodalomra: Grünvald-Scheiber, 1963: 5-48.; Varga, 1992: 59-79.

${ }^{7}$ Példák a földesúri privilégiumlevelekre: MZSO II. 169.; MZSO III. 177.; MZSO V/1. 744.; MZSO V/2. 195., 1069.

${ }^{8}$ Silber, 1990: 35.; Mislovics, 2008: 75-98.

${ }^{9}$ Varga, 1991: 34.; Kalmár, 1991: 43.

${ }^{10}$ Löw, 1840-1847: 54-105.; Bernstein, 1900: 599-629.; Mislovics, 2008: 259-319.

${ }^{11}$ Löw, 1807: 37-46.; Mislovics, 2008: 260-320.
} 


\subsection{A források időbeli megoszlása}

A két levéltári gyüjtemény kialakítása meghatározott intervallumon belül ad lehetőséget a belső források összegyüjtésére. Elméletileg a korszakhatár az A 39 jelzetü állagban 1770-1848, míg a C 55 jelzetü anyagban 1783-1848 közötti. ${ }^{12}$ Mindkét gyüjteményben vannak korábbi keltezésü dokumentumok is. (Jóllehet a Helytartótanács már 1724-ben megalapításra került, azonban az 1783 előtti iratok az Acta Judaeorum, 1725-1783 (C 29 Zsidóügyi iratok), illetve az Acta Religionaria, 1724-1783 (C 40 Vallásügyi iratok) anyagban kerültek elhelyezésre. ${ }^{13}$ )

Az A 39 jelzetủ állagban a legkorábbi belső forrás 1768-ból, Abaúj megyéből származik. Hungerleider Abraham és Polacsek Abraham elismerik, hogy Ginth Mária kassai lakos pénzt kölcsönzött számukra. A jiddis nyelven írt elismervényt Valla Johannes Emericus fordította latinra, és ebben a formában maradt fenn. ${ }^{14}$ A gazdasági kapcsolatok mellett a dokumentum rávilágít a korszakban megszokott eljárásra. Hiszen a későbbi vitás helyzetek miatt a gazdasági ügyletekben résztvevő feleknek egyaránt ismerniük kellett a kontraktusok, egyezségek szövegét. A C 55 jelzetủ állagban az első dokumentum 1772-ből maradt fenn, az óbudai közösség tagjai a Kamarához fordulnak a tolerancia taxa felosztása, illetve az adózással kapcsolatos panaszaik miatt. A 24 aláírást tartalmazó dokumentum nyelve latin. Maga a forrás nem az 1772. évi források között található. A levéltári rendezés az óbudai közösség 1817. évi anyagának aktái közé helyezte. ${ }^{15}$

Évtizedenkénti lebontásban a dokumentumok megoszlása a következőképpen alakul a két állagban:

\section{1. táblázat: A források időrendbeli és állag szerinti megoszlása évtizedes lebontásban}

Table 1.: Distribution of the sources by chronology and collection by decade

\begin{tabular}{|l|l|l|l|}
\hline & $\begin{array}{l}\text { Acta Generalia } \\
\text { (A 39) }\end{array}$ & $\begin{array}{l}\text { Departamentum } \\
\text { Judaeorum } \\
\text { (C 55) }\end{array}$ & Összes \\
\hline $1760-1769$ & 2 & & 2 \\
\hline $1770-1779$ & 47 & 1 & 48 \\
\hline $1780-1789$ & 36 & 148 & 184 \\
\hline $1790-1799$ & 7 & 160 & 167 \\
\hline $1800-1809$ & 9 & 239 & 248 \\
\hline $1810-1819$ & 20 & 243 & 263 \\
\hline $1820-1829$ & 41 & 319 & 360 \\
\hline $1830-1839$ & 29 & 392 & 421 \\
\hline $1840-1849$ & 23 & 275 & 298 \\
\hline Összes & 214 & 1777 & 1991 \\
\hline \multicolumn{3}{|c|}{ Forrás: Saját gyújtés alapján. } \\
\hline
\end{tabular}

Az Acta Generalia állagában a korszak folyamán 1760 és 1769 illetve 1790-1810 között viszonylag kevesebb belső forrásanyag található, míg a további időszakban 20-50 közé tehető a számuk ( 1 . táblázat). A Helytartótanács esetében 1780 után 1840-ig folyamatosan növekvő számban tartalmaznak az akták belső forrásokat. A számadatok kétirányú következtetésre adnak lehetőséget. A Kancellária szerepkörének változása miatt a középfokú törvényhatóságoktól beérkezö kérelmek, jelentések, vizsgálati anyagok aktái már a Helytartótanács elé kerülnek, utalva annak a közigazgatásban betöltött szerepkörére. A dokumentumok magas száma a szokásos eljárásokra is rávilágít, hiszen a zsidóságot érintő ügyek a földesúr, megye illetve később akár a Helytartótanács elé kerülhetnek. Az óbudai közösség 1784-ben az úriszék előtt kérelmezett kereskedési jog elnyerése érdekében, mivel a magánkereskedés tiltott számukra. Emiatt sem a földesúri, sem a további adókat nem képesek fizetni. ${ }^{16}$ Zsidó magánszemélyek, avagy közösségen belüli viszály ügye is eljuthatott a kormányszervi

\footnotetext{
${ }^{12}$ Wellman, 1951: 7., 35-40.

${ }^{13}$ Felhö, 1961: 91-94., 127-130.

${ }^{14}$ MNL A 39 1770. 436.

${ }^{15}$ MNL C 55 1817. 3. 5. (\% jelzettel).

${ }^{16}$ MNL C 55 1785. 4. (jelzet nélkül).
} 
fórumokhoz. 1819-ben a gyulafehérvári zsidóság emel panaszt a pozsonyi rabbi (Chatam Szofer) hatalmaskodása ellen. ${ }^{17} \mathrm{Az}$ óbudai rabbinak, Moses Minznek a förabbi hivatal elnyeréséért folytatott küzdelmének ügye, amely a közigazgatási értelemben vett érdekeltségi terület kiszélesítése mellett a vallási életet is érintette, ugyancsak eljutott a Helytartótanács és a Kancellária elé. ${ }^{18}$

\subsection{A források szerzői - aláírói}

A dokumentumok szerzői esetében elsőként az iratanyagok nyelvét szükséges megvizsgálni: latin, német, magyar nyelvű iratok találhatók a forrásanyagban. Gyakori, hogy egy-egy dokumentumot a szerzője héber betűs aláírással lát el, amely a közösségen belüli névhasználatát is felfedi. ${ }^{19}$ Feltételezhető, hogy nem minden esetben az aláíó az irat lejegyzője. Hiszen egy Lengyelországból pár éve betelepülő árendátor nem biztos, hogy tudott latinul írni. Minden bizonnyal a helyi vagy a közösségen belüli írástudók segítségét vették igénybe. Azonban az aláírásukkal hitelesítették a dokumentumokat.

Az állagokban fellelhető forrásanyag szerzői, aláírói kategóriái négy fő csoportra bonthatók:

2. táblázat: A források szerzői - aláirói

Table 2.:The authors and signatories of the sources

\begin{tabular}{|l|l|}
\hline Szerzö/Aláíró & Számuk \\
\hline Magánszemély & 1495 \\
\hline Magánszemélyek & 191 \\
\hline Közösség & 225 \\
\hline Közösségek & 80 \\
\hline Összes & 1991 \\
\hline
\end{tabular}

Forrás: Saját gyüjtés alapján.

A táblázat (2. táblázat) oszlopai alapján látható, hogy magánszemély, magánszemélyek, közösség, illetve közösségek által ellenjegyzett iratanyag található meg a levéltári gyüjteményekben. Az iratok döntő többsége egyetlen magánszemély jelentése, panasza, kérelme. Kohn Hersch kereskedö Pest város magisztrátusához esedezett tolerancia jogért 1802-ben. ${ }^{20}$ Pest, mint szabad királyi város nem engedélyezte a zsidóság megtelepedését, csak kivételes esetekben. A kérelmező a tolerancia jog birtokosaként az állandó városi lakhatást nyerhetné el. Előfordul azonban, hogy testvérpár avagy üzleti partnerek közösen nyújtanak be folyamodványt. A Vix testvérek Trencsén megyéhez fordulnak, hogy Zsolna szabad királyi városban lakhatási jogot szerezzenek. Ök az 1790/1. évi 38. tc. hatályára hivatkozva szeretnének a városban maradni. ${ }^{21}$

Mintegy 76 közösség, illetve 29 esetben több közösség belső forrása maradt fenn. Az iratok időtartamát tekintve ezek nem túl magas számok. Egy közösség kérelme rávilágít annak szervezettségi szintjére, gazdasági lehetőségeire. A felsőábrányi közösség a megválasztott, de be nem iktatott rabbihoz ír levelet 1828-ban. Ebben a késlekedés okaként a kereskedelem visszaesését, és az ezzel járó anyagi gondokat említi. Az ügy elhúzódását mutatja, hogy az irat az 1833-ban keletkezett további ügyiratokhoz került. ${ }^{22}$ Más esetben egy egész megye zsidósága nyújt be kérelmet a Helytartótanácshoz. Máramaros megye zsidó közösségei kifejtik, hogy mindösszesen öt-hat zsinagóga létezik a megyében. Mivel azokban későn kezdik az istentiszteletet, nem érnek haza. Megoldásul az szolgálna, ha magánházaknál is tarthatnának imádságot. Máramaros megyében mintegy 7936 zsidó lakos élt ekkoriban, akiknek jelentős része falvakban, elszórtan lakott. A vallási előírások miatt szombat bejövetele után nem lehetséges utazni, csak olyan helyen imádkozhattak, ahova gyalog el tudtak jutni. ${ }^{23}$

\footnotetext{
${ }^{17}$ MNL C 55 1819.3. 50. (jelzet nélkül).

${ }^{18}$ MNL C 55 1793. 9. 16. (24503. sz.); MNL C 55 1794. 4. 6. (14993. sz.)

${ }^{19}$ MNL C 55 1801. 1. 12.

${ }^{20}$ MNL C 55 1802. 1. 24. (A jelzettel)

${ }^{21}$ MNL C 55 1829. 1. 108. (NB jelzettel)

${ }^{22}$ MNL C 55 1833. 1. 27. (A jelzettel.)

${ }^{23}$ MNL C 55 1828. 1. 43. (4017. sz.)
} 


\subsection{A forrásanyag geográfiai szórtsága}

A fentebbiekből következő kérdés vajon az ország mely területén élő zsidóságnak a belső forrásanyagát őrizték meg az állagok gyüjteményei? A zsidóság újkori letelepüléstörténetében fontos hangsúlyozni, hogy az nem egy időpontban történt, a korszak folyamán több hullámban zajlott. Kezdetben igyekeztek egykori lakóhelyeikhez közel az ország határmenti megyéiben letelepedni. Ugyanekkor az országban törökellenes harcok is dúltak, emiatt a területi egység csak a 18. század harmadik évtizedére következett be (noha a déli területeken az uralkodó katonai őrvidéket jelölt ki, ahová zsidók csak engedéllyel telepedhettek le, illetve Erdély sem került a Magyar Királysághoz visszacsatolásra). ${ }^{24} \mathrm{~A}$ belső vándorlás a kezdetektől jellemezte a zsidó lakosságot, jóllehet ennek üteme a 18. század második felétől lendült fel. Megkezdődött a belsőbb, illetve a déli, délkeleti megyék felé húzódás. A zsidóság demográfia-, és gazdaságtörténetének elemzésekor gyakori, hogy a szakirodalom a 19. század történetírói által meghatározott geográfiai határokat veszik alapul. Azonban ez nem tükrözi sem a zsidóság településtörténetét, sem a gazdasági élet régióit. A két szempont alapján hat körzet és vizsgálati egység kialakítása tűnt megfelelőnek (jóllehet még az egyes régiókat is tovább lehetne „bontani”). ${ }^{25}$ Fontos hangsúlyozni, mivel egy-egy kérvényt több megye is benyújthatott, ezért a belső források száma látszólag „,növekszik” a besorolásukkal.

\section{3. táblázat: A források régiók szerint megoszlása}

Table 3.: Regional distribution of the sources

\begin{tabular}{|l|l|l|l|}
\hline & A 39 & C 55 & Összes \\
\hline Oberland & 59 & 178 & 237 \\
\hline Kis-Burgenland & 9 & 31 & 40 \\
\hline Középső & 65 & 1301 & 1366 \\
\hline Dunántúl & 14 & 43 & 57 \\
\hline Keleti & 40 & 184 & 224 \\
\hline Déli & 8 & 130 & 138 \\
\hline Egész Magyarország & 12 & 7 & 19 \\
\hline Összes & 207 & 1874 & 2081 \\
\hline
\end{tabular}

Forrás: Saját gyüjtés alapján.

A táblázat (3. táblázat) adatai a 18-19. századi történeti Magyarország szinte valamennyi megyéjére vonatkozóan tartalmaznak belső forrásokat. Az egyetlen kivétel Ugocsa megye, ahonnan nem maradt fenn belső irat. A zsidóság lélekszáma ugyan valóban nem kiemelkedően magas a megyében, 1037 fő (1830 körül). Összehasonlításképpen a Hajdú kerületben, ahol az 1830-as években Fényes Elek müve szerint 257 fö élt, a levéltári források alapján 314 fö, ${ }^{26} 4$ belső okirat is fennmaradt a Magyar Nemzeti Levéltár anyagában. A táblázat adatai szerint a régiókban megtalálható belső forrásanyag a középső régióban tekintélyes. Ez nem csupán annak a következménye, hogy ezen a területen esetleg valamilyen ok miatt gondosabban kerültek megörzésre a dokumentumok. A további régióktól való nagyarányú eltérés részben annak a ténynek köszönhető, hogy Pest, Buda és Óbuda települések elkülönítése nem történt meg a középső régiótól. A két szabad királyi város és Óbuda mezőváros vonzotta a zsidó letelepülöket. A városi hatóságok panaszáradattal fordultak a kormányszervekhez, mivel a tiltás ellenére

\footnotetext{
${ }^{24}$ Bánát: MZSO III. 458.; Temesvár: III. 477.; Szerém és Verőcze: MZSO XIV. 75., 76.

${ }^{25}$ A szakirodalomban korábban kialakított geográfiai vizsgálati egységek (Duna bal partja, Duna jobb partja, Duna-Tisza köze, Tisza jobb partja, Tisza bal partja, Maros és Tisza által behatárolt terület, Erdély, (HorvátországSzlavónia) Ernö, 1966.) a korszakban semmiképpen sem felelnek meg a zsidóság település- és gazdaságtörténeti régióinak. A megyénkénti vizsgálat pedig szintén torz képet eredményezheti, mivel azok határai nem alkotnak gazdasági lezáróvonalat. Mislovics, 2008: 10.

${ }^{26}$ MNL HBML IV. 502. b. 1821. 1. 54.; 1836. 7. 12.; Fényes, 1839: 152-154.
} 
a zsidó lakosok száma folyamatosan emelkedett a településeken (kiváltképpen Pesten). Az ideiglenes (commorans) joggal bíró zsidó lakosok 1840-ig beadott kérelmei az állandó lakhatási jog elnyeréséért a belső források számát növelték. Másfelől megerősítik az adatok azt a feltételezést, hogy a megyei leváltárak rejthetik a vidék zsidóságának belső forrásait. Pest megyében 1830 körül a zsidóság lélekszáma mintegy 18000 fö volt, hasonlóan Nyitra megyéhez, míg Zemplén megyében mintegy 15000 fö élt. Pest megyében a fennmaradt belső források száma 1169, Nyitra megyében 50, Zemplénben mindösszesen 25.

\subsection{A belsö források címzettjei (illetve tanúvallomások esetén azok lejegyzöi)}

4. táblázat: Belsö források címzettjei

Table 4.: Recipients of the internal sources

\begin{tabular}{|l|l|}
\hline & Források száma \\
\hline Uralkodó & 235 \\
\hline Helytartótanács & 1068 \\
\hline Kancellária & 14 \\
\hline Városi hatóság & 438 \\
\hline Megyei hatóság & 99 \\
\hline Helyi (falvak) hatóság & 88 \\
\hline Földesurak & 37 \\
\hline Zsidó közösség & 12 \\
\hline Összes & 1991 \\
\hline
\end{tabular}

Forrás: Saját gyüjtés alapján.

A táblázat (4. táblázat) alapján a gyüjteményekben a Helytartótanácshoz címzett kérelmek, jelentések túlsúlya a jellemző. Mindez nem meglepő, hiszen a középfokú megyei közigazgatási szervektől eljuttatott iratanyagokhoz csatolták a kérelmezö saját felterjesztését, amelyet már közvetlenül a felsőbb kormányszervhez írt. Noha az A 39 jelzetü gyüjtemény a Kancellária iratanyagát tartalmazza, így is csupán 14 irat címzettje. Erre a megoldás az uralkodónak közvetlenül címzett kérelmek, jelentések viszonylag magas számában keresendő. 1770-ben Mandl Abraham, Breisach David, Herschl Wolf pozsonyi kereskedők az uralkodóhoz fordultak, mivel árujuk szállítása közben hajójuk elsüllyedt. Káruk enyhítésére adózási kedvezményért, valamint külföldi áru behozatalának az engedélyéért esedeztek. ${ }^{27}$ Ugyanakkor ezek az iratok átkerültek a Kancelláriához (amelynek tagjai kézjegyükkel látták el az okiratokat). Majd pedig a Kancellária ezeket a Helytartótanács felé közvetítette többnyire. Mária Terézia a tolerancia taxa ügyei során hozzá érkező panaszáradat miatt arra utasította a megyéket, hogy a zsidó közösségek esetében tartsák kézben az adózási ügyeket, és ne engedjék, hogy azok a megyét megkerülve közvetlenül panaszt nyújtsanak be a felsőbb fórumokhoz. ${ }^{28}$ Ezért a belső források többsége egy-egy ügy mellékleteként kerül csatolásra a megyétől a kormányszervekhez elküldött iratanyagban. Feltünően magas a városi hatóságokhoz írt kérelmek sokasága. Ezek mintegy 29 városhoz érkeztek, jóllehet döntő többségükben Pest (279) és Buda városához (49) írt kérvények szerepelnek a gyüjteményben. Összehasonlításképpen Kassa és Pozsony városi hatóságaihoz mindösszesen 13-13 íródott. A városi polgárság és a zsidóság közötti feszült viszony a korszak folyamán nem enyhült. A városi hatóságok igyekeztek érvényt szerezni a középkorban elnyert kiváltságuknak, azaz nem kell megtürniük zsidó lakosokat a városfalakon belül. A szabad lakhatásért folyamodó kérvények növekvő száma mégis döntően a városfalakon belül élő zsidó lakosok kéréseit tartalmazta. II. József engedélyezte 1783 után a városokban való megtelepedést. Azonban az 1790/91. évi 38. tc. a zsidóság helyzetét az 1790. január elsejét megelőző állapotában rögzítette, amelyet a városi polgárság úgy értelmezett, hogy további

\footnotetext{
${ }^{27}$ MNL A 39 1770. 1012.

${ }^{28}$ MZSO XV. 205., 206.
} 
megtelepedőket nem kell befogadniuk a városba. Másfelöl a városi hatóságnak szembe kellett néznie azzal a ténnyel, hogy a városfalakon kívül a földesúri mezővárosokban jelentős számú zsidó közösségek alakultak ki: Pozsony körül Schossberg és Czukkermandl, Nyitra körül Parutza mezővárosban. Az itt élők gazdasági tevékenységeiket a városfalakon belül is folytatták, amit a városi polgárság a gazdasági érdekek, valamint a földesúri támogatás miatt sem tudott megakadályozni. A városi lakhatást kérelmezők száma folyamatosan emelkedett. Az ideiglenesen vásárok időszakában, télvíz idején beköltöző commorans zsidó lakosok gyakran évekig a városban maradtak. Varasd városában Tatzer Volf már 17 éve élt ideiglenesen. ${ }^{29}$ Noha az 1840. évi 29. tc. biztosította a zsidóság szabad megtelepedését a szabad királyi városokban, a kérelmek tartalma nem erről tanúskodik. 1847-ben Lusztig Lipót a városi hatóságok nemleges döntése után a Helytartótanácshoz fellebbez. Lakhatási kérelmét a városi hatóság egy állítólagos hamis váltóra hivatkozva utasítja el, a kérelmező ezt tagadja. ${ }^{30}$ A táblázat adatai alapján igen kevés belső dokumentum címzettje a földesúr, illetve a zsidó közösség. Ezek az ügyek csupán kivételes esetekben jutottak el magasabb fórumokig (a rabbi a fizetés elmulasztásakor panaszt emel a földesúrhoz, közösségi viszály esetében ${ }^{31}$ ).

\subsection{A belső források megoszlása tárgyuk alapján}

A belső források tárgyukat tekintve igen sokszínüek, ezért hét fö kategóriacsoport kialakítása történt meg:

5. táblázat: A belső források megoszlása tartalmuk alapján

Table 5.: Distribution of the sources on the basis of their contents

\begin{tabular}{|l|l|}
\hline Tárgy & Források száma \\
\hline Gazdaság & 517 \\
\hline Letelepedés & 916 \\
\hline Migráció & 323 \\
\hline Vallási ügyek & 261 \\
\hline Oktatás & 6 \\
\hline Igazságszolgáltatási ügyek & 65 \\
\hline Egyéb & 181 \\
\hline Összes & 2269 \\
\hline
\end{tabular}

Forrás: Saját gyüjtés alapján.

A tárgyi besorolás alapján a források magasabb száma abban a tényben rejlik, hogy az egyes dokumentumok akár több tárgyban is tartalmazhatnak panaszt, kérelmet avagy jelentést (5. táblázat). Ezek a csoportok szinte soha nem homogének, mindenkoron több területet foglalnak magukban.

A táblázat kategóriái sugalmazzák a korszakban a zsidó társadalom megitélésében fontos témákat. Migráció, megtelepedés, a belső vándorlás során új lakóhely keresése alkotja az iratok igen jelentős részét (mintegy 1239 dokumentum). A vizsgált korszak kezdetén a Magyar Királyság szinte elnéptelenedett területére számos letelepedő érkezett. A levéltári források azt is alátámasztották, hogy a moráviai, bohémiai és lengyelországi zsidóság nem csupán egy meghatározott időszakban, hanem az egész korszak folyamán érkezett az országba, jóllehet az egyes irányokból az egyes időszakokban változó intenzitással. Egy 1832-ből származó forrásban Kohn Vilhelm moráviai bevándorló több kéréssel fordul a Helytartótanácshoz. Szeretne Magyarországra vándorolni, pontosabban ennek elismertetését kieszközölni, hiszen már az országban él. (Az ilyen típusú kérelem nem egyedi.) Pest városában szeretne letelepedni, amely szabad királyi város, és a polgársága élénken tiltakozik zsidó lakosok befogadása ellen. Kohn Vilhelm a jogszerü megtelepedés érdekében kéri a Helytartótanács közbenjárását, hogy eszközölje ki számára a honából való elbocsátási engedélyt. Kérése indoklásaként megemlíti, hogy a Földváry család pártfogása alá érkezett. Ez utóbbi megjegyzés egy igen fontos tényre

\footnotetext{
${ }^{29}$ MNL C 55 1811. 4. 6. (5810. sz.)

${ }^{30}$ MNL C 55 1847. 5. 91.

${ }^{31}$ MNL C 55 1846. 2. 32. (38867. sz.); MNL C 55 1839. 9. 2. (31033.sz.)
} 
világít rá. A bevándorlás kezdeti időszakában a földesurak letelepítették avagy engedték a birtokaikon a megtelepedést. Azonban a korszak folyamán a letelepedés spontánabbá vált. A fenti forrás azonban igazolja, hogy a földesúri pártfogás intézménye megmaradt. A Helytartótanács a Morva Gubernórium felé továbbítja a kérést az engedély elnyeréséért. ${ }^{32}$

A letelepedés forrásanyaga a jogi útvesztőket állítja a középpontba. Az újkorban 1783-1790 közötti rövid időszak kivételével a városi hatóságok érvényesítették a 'de non tolerandis Judaeis' jogát. A városi megtelepedés lehetősége számos akadályba ütközött, ahogyan a fentebbi említett példák bemutatták. Ezek megkerülése beházasodással vált lehetségessé. 1833-ban Hertzberger Simon quaestor, aki Pozsonyból érkezett, már 9 éve Pest városában élt. Lustig Wolf lányával házasodott össze. Ố csupán commorans jogért esedezik (ez ideiglenes lakhatást jelent). Indoklásában kifejti, hogy adót fizet és jó magaviseletü. ${ }^{33}$ Meglepőbb azonban Berger Simon irsai kereskedő következő kérelme 1841ből. Irsáról Ceglédre szeretne költözni, ahol kereskedelmi tevékenységet folytatott már a korábbiakban is. A kérelem két ok miatt is figyelmet érdemel. Ahogyan a kérelmező maga is kifejti az 1840. évi 29. tc. engedélyezte a magyarországi születésü izraelitáknak az ország bármely településén való megtelepedést. Másfelől Cegléd nem szabad királyi város, hanem mezőváros volt ekkoriban. Ezért nem vonatkoztak rá a szabad királyi városi jogok. ${ }^{34} \mathrm{Az}$ említett törvényt a városi hatóságok igyekeztek semmibe venni. Ennek egyik példája Kassa szabad királyi város izraelita lakosainak panasza a vármegyéhez 1841-ben. Nem csupán nem engedélyezi a város a szabad megtelepedést, a hatóságok elüzéssel fenyegetik öket. A városi kapitány öt napot adott számukra lakóhelyük elhagyására télvíz idején. ${ }^{35}$

Ugyancsak jelentős a gazdasági élet területéről származó belső források száma, mintegy 517 dokumentum. A gazdasági csoport nem homogén, számos alcsoportba sorolható irat tartozik ide a következő témákat érintve: adóztatás (amelynek további alcsoportjai a tolerancia taxa, megyei, földesúri taxa), árendaszerződések, iparüzés joga, kereskedelem, tulajdonjog. A magyarországi gazdasági helyzet, a piachálózat újbóli kiépítése megkívánta közvetítők jelenlétét. Erre a feladatra a polgárság gyenge rétege nem vállalkozhatott, a magyar nemesség elutasította, míg a jobbágyság nem volt képes betölteni. Az országba vándorlók közül a görögök, örmények és zsidók vállalták magukra e szerepkört. ${ }^{36}$ A zsidóság az újkori megtelepedése során a középkori korlátozásokkal szembesült. A belső források a gazdasági életben betöltött helyükről, a felmerülő akadályokról is árulkodnak. A zsidó lakosokat a társadalom más tagjaitól elkülönítve egy külön adó is sújtotta, a tolerancia taxa. Ennek mértéke kezdetben $20000 \mathrm{ft}$ volt, majd folyamatosan emelkedett és az 1810-es években (a pénz devalvációja után) elérte a 160000 ft-ot. A zsidó közösségek között a felosztás meghatározása az adó állandósításának időszakában (1749) fennálló megyei népességviszonyokat tükrözte, amely a 19. századra elavulttá vált. Az adófizetés könnyítéséért a beérkező kérvények száma nem apad a korszakban: így 1782-ben a stompfai, ${ }^{37}$ 1796-ban a nagymartoni, ${ }^{38} 1814$-ben a Tolna megyei, ${ }^{39} 1823$-ban a Szabolcs megyei,${ }^{40} 1837$ ben a Szepes megyei zsidóság az uralkodóhoz könyörög. ${ }^{41}$ Az adó fizetésének felfüggesztése abban az esetben vált ideiglenesen lehetségessé, ha valamilyen kár érte az egyes közösségeket. 1778-ban Sassin közösségében tüz pusztított, ezért kérnek az adó fizetésére haladékot. ${ }^{42}$

A letelepedő zsidó lakosoknak mesterségük gyakorlása érdekében engedélyhez kellett folyamodniuk. A földesúri birtokokon kiadott privilégiumlevelek magukban foglalták ezeket a jogokat. Magyarországon még az 1840-es években is virágzott a céh, amelynek tagjai féltékenyen őrködtek kiváltságaik felett.

\footnotetext{
${ }^{32}$ MNL C 55 1832. 1. 14. (19233. sz.)

${ }^{33}$ MNL C 55 1833. 1. 120. (18746. sz.)

${ }^{34}$ MNL C 55 1841. 5. 241. (39710. sz.)

${ }^{35}$ MNL C 55 1841. 5. 94. (18080. sz.)

${ }^{36}$ Pach, 1985: 132-161.; Petri, 1996: 69-104.; Mislovics, 2008: 164-173.

${ }^{37}$ MNL A 39 1782. 2266.

${ }^{38}$ MNL A 39 1796. 1. 170. (16985. sz.)

${ }^{39}$ MNL A 39 1814. 791.

${ }^{40}$ MNL A 391823.6932.

${ }^{41}$ MNL A 39 1837. 550/30.

${ }^{42}$ MNL A 391778.493.
} 
1829-ben az óbudai zsidó szabók a helyi szabócéh privilégiumai ellen kérelmeznek az uralkodóhoz. ${ }^{43}$ Maguk a zsidó lakosok is létrehoztak saját céheket. 1830-ban a pápai zsidó szabók céhprivilégum elnyeréséért esedeznek az uralkodóhoz. ${ }^{44}$ A zsidó céheken belül ugyanúgy létezett az etikai kódex, miként a keresztény társaságban. 1832-ben Grosz Elias nyírbátori tímármester saját bevallása szerint egyik éjszaka kiabálást hallott, ahol a helyi metszőt egy katonaviselt lengyelországi zsidó lakos szidalmazta. Meglátva őt, tolvajnak nevezte. Amíg a becsülete nincs tisztázva, nem viheti tovább a mesterségét a céhben. ${ }^{45} \mathrm{~A}$ céhen kívüli, már kiváltságolt zsidó mesterek maguk is igyekeznek minden új kérelmező útját gátolni. 1836-ban a pesti Adlitzer Simon és Spitzer Hermann arany- és ezüstmüvesek Kohn Isac új segédje ellen emelnek panaszt a Helytartótanácsnál. A kérelmezők vélekedése szerint a segéd, Weiss Philipp commorans jogért való kérelme, iparüzési tevékenysége mind a zsidó, mind a keresztény társadalomnak gazdasági károkat okozna. ${ }^{46}$

A belső források következő, hasonlóképpen színes tartalmú csoportjai a vallási kategória keretei közé tartoznak (áttérés, házasság, rabbi választása, hatásköre, zsinagóga, temető, fürdő). A vallási ügyek a zsidó közösség körében kerültek megvitatásra. Azonban egy részük eljutott a magyarországi legfelsőbb fórumokhoz. A főrabbiság intézményének a kialakítása során 1795-ben az óbudai rabbi ellen a pesti közösségek egy része elutasítóan lép fel, nem fogadják el vallási és ceremoniális ügyekben a hatáskörének a kiterjesztését, hiszen van saját rabbijuk. ${ }^{47} \mathrm{~A}$ rabbi választása sem mindig zajlott békés úton egy-egy közösségben. 1847-ben a korszak egyik legelismertebb rabbiját, Lőw Leopoldot a pápai közösség egy része nem kívánta elfogadni. Vélekedésük szerint erőszakosan választották meg, valamint a rabbi vallástalansága közismert. ${ }^{48} \mathrm{~A}$ választás küzdelmeiben a hagyományos értékrend védelmezőinek, valamint az újító eszmék befogadóinak az összecsapásának egy fejezete bontakozik ki a kérelmek alapján.

A vallásnak léteztek olyan területei, amelyekben a társadalom tagjaival való egyeztetés elkerülhetetlennek számított. A zsinagóga, temető, fürdő esetében a földterület és a ház bérlete miatt szükséges kérelmezni. Hiszen a zsidó lakosok nem birtokolhattak sem épületet, sem földet, csak bérelhették azokat. 1841-ben egy, a Helytartótanácshoz eljuttatott kérelmet 90 balassagyarmati kérelmező írt alá, mivel a zsinagóga építése miatti esedezésüket Nógrád megye nem tárgyalta, ezért felsőbb fórum felé fordultak. ${ }^{49}$ Nógrád megye a bányavárosok közelsége miatt bizonyos területeire nem enged zsidó lakosokat betelepedni, és igyekszik gátolni a már a megyében élők közösségi élet kialakítására tett lépéseit. Egészen más képet mutat a lengyeltóti közösség 1845-ben keletkezett jelentése Somogy megye közgyülése felé. Ebben a lengyeltóti közösség a környező területek zsidó lakosaival egyetértésben a vallási intézményeinek kialakítását, azok tulajdonban való megszerzését, illetve a közösség jövőbeli müködésének a szabályait rögzíti. ${ }^{50}$

Az oktatási kategóriában látszólag kevés dokumentum maradt fenn. Valójában nehéz a vallási ügyek csoportjától elkülöníteni a forrásokat. A közösségek oktatási ügyébe való beavatkozás II. József Systematica gentis Judaicae regulatiojához köthető, aki 1783-ban elrendelte iskolák felállítását, avagy állami iskolák látogatását minden zsidó fiatal számára. ${ }^{51}$ A kezdeti tiltakozás ellenére a közösségek létrehoztak iskolákat, illetve ha nem, a környékbeli intézményekbe íratták gyermekeiket. Legtöbbször egy-egy kérelem nem csak az oktatásra vonatkozik, ahogyan ezt 1827-ben Chorin aradi rabbi Helytartótanácshoz írt esedezése mutatja, ő zsinagóga és iskola megalapításának a lehetőségét kéri. ${ }^{52}$ 1834-ben a máramarosszigeti közösség egyik tagja, Davidovics Abraham a zsidó közösség iskola fenntartásának megszüntetéséért folyamodott, illetve hogy a tanulók a helyi iskolákba járhassanak. A máramarosi zsidó bírák ezt ellenzik, mert egy helyi református iskolába kellene a gyerekeket beíratni.

\footnotetext{
${ }^{43}$ MNL A 39 1829. 11883/1547.

${ }^{44}$ MNL A 39 1830. 1700/116.

${ }^{45}$ MNL C 55 1833. 1. 47. (695. sz.)

${ }^{46}$ MNL C 55 1836. 5. (5119. sz.)

${ }^{47}$ MNL C 55 1794. 4. 6. (14993. sz.)

${ }^{48}$ MNL C 55 1847. 2. 20. (12821. sz.)

${ }^{49}$ MNL C 55 1841. 2. 4. (20342. sz.)

${ }^{50}$ MNL C 55 1847. 2. 62. (a jelzet).

${ }^{51}$ MNL A 39 1782. 4668.

${ }^{52}$ MNL C 55 1827. 4. 55. (11984. sz.)
} 
Állításuk szerint a fiatalok nem beszélik jól a magyart és a németet. Sőt végső indokként kifejtik, a gyermekek a szülők gondatlansága miatt rühesek, ez pedig keresztény tanulótársaik megbetegedéséhez vezetne, ami csak a gyülölködést szítana. ${ }^{53} \mathrm{~A}$ belső információk ilyen mértékü részletezése sokkal inkább a meggyőzést szolgálja, illetve annak a ténynek köszönhető, hogy a zsidó közösség maga kívánja intézni a gyermekek nevelését a zsidó vallásra helyezve a hangsúlyt. Máramarosszigeten a hagyományos értékrend védelmezői hevesen ellenezték a világi tudományok (magyar nyelv, német nyelv, számtan, mértan, földméréstan) oktatását. Az oktatási ügyekre vonatkozó dokumentumok az állami beavatkozásokról és a közösség körében kialakuló irányzatokról is számot adnak.

Az igazságszolgáltatási ügyek csoportjai közé tartoznak a polgári és büntetőperes ügyek. Az újkorban a zsidóság letelepítésében illetve letelepedésének engedélyezésében a földesurak játszottak aktív szerepet. Ahogyan a korábbiakban említésre került, védelmezték a területeiken élő zsidó lakosokat, gazdasági jogokat biztosítottak számukra, de rögzítették elvárásaikat is. Segíthették a vallási élet kereteinek a kialakulását, így a Péchy család házában gyakorolhatta a pécsújfalusi zsidóság az istentiszteletet 1773ban.$^{54} \mathrm{Nem}$ minden esetben alakult azonban békésen a viszony a két fél között. Számos alkalommal hatalmaskodás ügye kerül a felsőbb fórumok elé. 1792-ben a Nagykárolyban élö Benjamin Moses panaszt emel a vármegyéhez, mivel Patay József földesúr magával vitte a lányát és minden vagyonát. A per során a kérelmező esélyeit rontja, hogy a földesúr barátai folytatták le a vizsgálatokat. ${ }^{55}$

Az egyéb kategória olyan dokumentumokat rejthet, amelyek adoptálási ügyekre, magyarosodás a zsidóság körében, avagy a letelepedési kérelmeik mellé csatolt eredeti dokumentumaik visszaigénylésére irányult. ${ }^{56} \mathrm{~A}$ városi letelepedés során kérelmezett iratanyaghoz Hollander Georg csatolta az eredeti iratait. A jegyző azonban nem juttatja vissza azokat. ${ }^{57}$ A magyarosodás ügyében Diamant Simon Pest megyéhez ír kérelmet 1842-ben. Ebben kifejti, a zsidóságon belül felütötte a fejét a pártérdek és nem mindenki a magyar nyelv terjesztése érdekében lép fel. Ezért a pesti hitközség tisztújító közgyülésén olyan tagokat kell megválasztani, akik ezt a feladatot tủzik ki célul. Mind a megye, mind a Helytartótanács segítségét remélte, azaz a zsidóság belső ügyeibe akar állami beavatkozást. ${ }^{58}$ Sorai kifejezésre juttatják a magyar állam felé a lojalitást, amelynek egyre nagyobb jelentősége lesz az 1840-es évektől kezdődően.

\section{A forrásanyag kutatásának tanulságai}

A kormányszervi levéltárak anyagában a zsidóság történelmére vonatkozóan bőséges belső forrásanyag áll rendelkezésre. Ezek a dokumentumok hozzájárulnak a zsidóság történelmének alaposabb megismeréséhez letelepedésükre, gazdasági, kulturális, vallási életükre és a keresztény társadalommal való kapcsolatrendszerükre vonatkozóan. Ugyanakkor a belső források döntő többsége a Pest megyei, azon belül is a Pest városában élő zsidóság anyaga. Az újkori Magyar Királyságban élő zsidóság történelmének megismeréséhez célszerü ezeket a belső forrásokat felkutatni más megyékben is. Ezért a kutatásban jövőbeli célként fogalmazódhat meg a megyei levéltárak anyagainak átnézése. Ez lehetőséget biztosít annak összevetésére, hogyan egészíti ki az Országos Levéltár állagaiban megtalálható iratanyagot a megyei levéltári anyagok gyüjteménye. Ugyancsak elörelépést jelenthetne olyan adatbázis kialakítása, amely jelzet, név, hely, tárgymutató, rövid regeszta feltüntetésével összekapcsolná az országos és megyei levéltárakban fellelhető forrásokat. A rendelkezésre álló belső forrásanyag a 17-19. századi zsidóság eddig ismert történelmét árnyalhatja és új ismeretekkel gazdagithatja.

\section{Irodalomjegyzék}

A bonyhádi zsidó közösség kérelme. Közölte: Büchler S. Magyar Zsidó Szemle. 1894. 657-666.

\footnotetext{
${ }^{53}$ MNL C 55 1834. 2. 17. (:///: jelzet).

${ }^{54}$ MNL A 39 1773. 387.

${ }^{55}$ MNL C 55 1793. 2. 1. (Nr. 5.).

${ }^{56}$ MNL C 55 1833. 3. 89.

${ }^{57}$ MNL C 55 1841. 5. 99. (Nb jelzet).

${ }^{58}$ MNL C 55 1843. 1. 81/2.
} 
Bernstein B. (1900): Die Toleranztaxe de Juden in Ungarn. In: Brann, M. - Rosenthal, F. (szerk.): Gedenbuch zur Erinnerung an David Kaufmannn. Breslau, 599-629.

Ernő L. (1966): Hungarian Jewry: Settlement and Demography 1735-1738 to 1910. In: Braham, L. R. (szerk.): Hungarian Jewish Studies. New York. 61-136.

Felhö I. (1961): A helytartótanácsi levéltár. Magyar Országos Levéltár kiadványai I. Levéltári Leltárak 3. Budapest.

Fényes E. (1839): Magyar országnak 's a' hozzá kapcsolt tartományoknak mostani állapotja statistikai és geographiai tekintetben. V. Bp., 1839.

Grünvald F.-Scheiber S. (1963): Adalékok a magyar zsidóság településtörténetéhez a XVIII. század elsö felében. In: Grünvald F.-Scheiber S. (szerk.) (1980): Magyar-Zsidó Oklevéltár VII. Budapest. 5-48.

Kalmár J. (1991): A Kollonich-féle Einrichtungswerk és a 18. századi bánsági berendezkedés kérdése. Századok. 5-6. sz. 489-499.

Komoróczy G. (2012): „Nekem itt zsidónak kell lenni.” Források és dokumentumok (965-2012). A zsidók története Magyarországon I-II. kötetéhez. Szöveggyüjtemény. Kalligram. Budapest.

Lőw L. (1840-1847): Die Schicksale und Bestrebungen der Juden in Ungarn. In: Busch I. (szerk.): Calendar und Jahrbuch für Israeliten. Bécs. 54-105.

Lőw L. (1874): Protokoll der Zirkular-Deputation in Betreff der Regulirung der Juden. Verfast am 24. Nov. 1807. In: Lőw L. (szerk): Zur neueren Geschichte der Juden in Ungarn: Beitrag zur allgemeinen Rechts-, Religions- und Kulturgeschichte. Budapest. 53-62.

Mislovics E. (2008): A magyarországi zsidóság demográfia- és gazdaságtörténete. PhD. Hebrew University.

MNL A 39: Magyar Nemzeti Levéltár, Magyar Kancelláriai Levéltár, Acta Generalia 1770-1848.

MNL C 55: Magyar Nemzeti Levéltár, Magyar Helytartótanácsi Levéltár, Departamentum Judaeorum $1783-1848$.

MNL HBML IV. 502.b: Magyar Nemzeti Levéltár Hajdú-Bihar Megyei Levéltára, Hajdúböszörményi Fióklevéltár, A Hajdúkerület Közgyülésének iratai. Közgyülési iratok/1605-/1713-1848.

MZSO I.: Friss Á. (szerk.) (1903): Magyar-Zsidó Oklevéltár. I. Budapest.

MZSO II.: Mandl B. (szerk.) (1937): Magyar-Zsidó Oklevéltár. II. Budapest.

MZSO III.: Mandl B. (szerk.) (1937): Magyar-Zsidó Oklevéltár. III. Budapest.

MZSO V/1.: Grünvald F. - Schreiber S. (szerk.) (1959): Magyar-Zsidó Oklevéltár. V/1. Budapest.

MZSO V/2.: Grünvald F. - Schreiber S. (szerk.) (1960): Magyar-Zsidó Oklevéltár. V/2. Budapest.

MZSO XIV.: Schreiber S. (szerk.) (1971): Magyar-Zsidó Oklevéltár. XIV. Budapest.

MZSO XV.: Schreiber S. (szerk.) (1972): Magyar-Zsidó Oklevéltár. XV. Budapest.

MZSO XVIII.: Schreiber S. (szerk.) (1980): Magyar-Zsidó Oklevéltár. XVIII. Budapest.

https://kisebbsegkutato.tk.mta.hu/adatbazis/magyar-zsido-okleveltar

Pach Zs. P. (1985): Üzleti szellem és a magyar nemzeti karakter. Études historiques hongroises.

Budapest. Vol. II. 132-161.

Petri E. (1996): A görögök közvetitö kereskedelme a XVII-XIX. századi Magyarországon. Századok. 69104.

Silber, M. K. (1990): The Jews in the Hapsburg Empire. In: Friesel, E. (szerk.): Atlas of Modern Jewish History. New York-Oxford, Oxford University Press. 34-35.

Spitzer, S. J. - Komoróczy Géza (szerk.) (2003): Héber kútforrások. Magyarország és a magyarországi zsidóság történetéhez a kezdetektöl 1686-ig. MTA Judaisztika Kutatócsoport - Osiris Kiadó. Budapest.

Varga L. (1992): Zsidó bevándorlás Magyarországon. Századok. 1. sz. 59-79.

Varga J. J. (1991): Berendezkedési tervek Magyarországon a török kiüzésének az idöszakában. Az „,Einrichtungswerk”. Századok. 5-6. sz. 449-488.

Wellman I. (1951): A Magyar Kancellária Levéltára. Budapest. 